\title{
Local Wisdom Discourse: Appearance Of Art In Tayub Dance In Sragen Gesi Village
}

\author{
Septa Suryanto ${ }^{1}$, Mugijatna $^{2}$, Susanto $^{3}$ \\ \{1 septa_suryanto@yahoo.co.id, 2ykmugijatna@gmail.com, ${ }^{3}$ sussastra@gmail.com\} \\ ${ }^{1,2,3}$ Sebelas Maret University of Surakarta, Indonesia
}

\begin{abstract}
Tayub art is one of the many types of traditional art in Central Java. In the past tayub art was a traditional folk art which had a special place from the Palace to the lower classes. The tayub performance in Sragen is one of the traditional forms of art in Sragen Regency. The art form of tayub in the Sragen region itself is a form of rearrangement by the government in collaboration with related agencies and artists and artists. This research is positioned in the system of critical thinking using critical theory in the postmodern paradigm. Michel Foucault's theory of discourse is positioned as the main theory to reveal knowledge, relationships and power. Based on the studies conducted, conclusions can be formulated. The discourse that is built is caused by the situation faced by society under the pressure of modernity and capitalism which penetrates the joints of the people's economy. The process of local wisdom discourse: performing arts in tayub dance that is forming a knowledge, where knowledge is contained in a high philosophy that is where tayub art is likened to a life that exists in humans, and power is in tledek, pengarih and penglarih. These names have their respective ways. Commodification of society in modernity, from ordinary women to dancers. The discourse on local wisdom has several implications, namely in developing the economy of ordinary family families becoming dancers by self-taught methods, increasing the income of the surrounding community, increasing the socioeconomic level of the family and as a tourist asset of the Sragen Regency Government.
\end{abstract}

Keywords: Discourse, Local Wisdom, Tayub Art, Sragen

\section{Introduction}

Tayub art is a traditional art that first appeared in the era of Singosari kingdom. Tayuban as a tradition of the people of East Java, Central Java, and Yogyakarta Special Region. Actually it's just a form of dance. As with Cokek, which is known in Betawi culture. In the assumption of cultural anthropology, many cultures are born from a painful historical event. Why do I mention painful because the feeling of distress as a result of life in the feudal and colonial era was transformed into a form of performance art. Although from the beginning tayub was gambyong palace art, in its development it had to come out and be degraded into folk art, which was increasingly seen from the sordid side, was of poor quality, and had a 
prostitution tendency. Prof. Dr. Suripan Sadi Hutomo (late), philologist and humanist folklore, once described that at a lower level of folk art, tayuban underwent a change.

This art is called janggrungan, where waranggono (ronggeng, tandak, kledek, taledek, teased) ngibing among the blandhong (woodcutter) on the edge of the forest for the sake of living. Cliffort Geertz called him a street dancer - in Yogyakarta known as mbarang - who often also ngamen from house to house or in a crowd. In fact, by tracing tayub from the etymological study, the opposite condition will be found. Soegio Pranoto-tayub elder from Nganjuk-mengirirabasa-tayub as arranged ben ben jub (arranged to create harmony), a philosophy that is embedded in tayub as an art for association. The basic value is the common interests to appreciate the ability, soul, and artistic talent, both the ability as gamelan musicians (pengrawit) or dancers. This similarity will give birth to harmony in tayub as a form of dance; the pounding of the foot in accordance with the sound of the drum, the hand waving in rhythm in the xylophone, or the head swing at each stroke of the gong. Tayub is a kind of banquet dance, which is presented to guests at the marriage hajad among Javanese people, in Tayuban guests take turns dancing "Tayub" in front of a tayub dancer who is also called taledhek.

The meaning of the word tayub through an article entitled Najub, Najuban; (Read; Nayub, Nayuban), Poerbotjaroko gives an explanation that Nayub is not derived from the word tayub, but it comes from the word Sayub which means liquor or also to refer to stale food; by discarding the final letter turns into glazed which in Javanese Krama becomes sajeng, which means liquor; because the exchange "s" becomes "w" turns into a skillet or liquor (Bharatayudha poem II verse 10). The form of ngoko from wajeng is wayu which is half stale or tape into tape.

In the Mangkunegaran notes there is also a statement that nayub is derived from the word tayub which consists of two words namely mataya which means dance, and guyub which means getting along together. So it is thought that there will be a change from two words to one: ma-taya and gu-yub become tayub.

The origin of tayub Some experts argue that tayub according to oral tradition if it is assumed or dijarwodosokan to be arranged cikben guyub which means "the dance is well arranged so that it becomes a harmony of people". While other opinions say that the word Tayub means "Kasukan jogogan and nganggo trapped by tledhek" which means to have fun dancing with tledhek dancers. In short it can be said that nayub means dancing and others say that nayub means dancing which has to do with drinking.

Tayub is an expression of art produced by supporting communities. Because basically, every work of art is representative of the community settings in which the art is produced. Some were born in the palace, middle class, and people circles. In this case, tayub art can be categorized as art that was born in the community, as stated by Arnold Hausser in Surtia Ningsih divides the art community into four groups [1], namely as follows.

1. Elite cultural arts, namely people who live from the development and advancement of their knowledge, which are concerned with aspects of spirituality and intellect, respecting the things that are original, unique, individually always new in the spiritual treasury of mankind.

2. Popular cultural arts, namely people who uphold professionalism, logical way of thinking, appreciative artistic tastes, and have conventional values that are usually from military academy graduates, medical professionals, business people, etc.

3. Mass art, namely people who are on average low educated, they like things that are sentimental, violent, horror, and sexuality. Every work of art is considered to be of high value depending on its fanaticism. 
Folk art, namely the art of spontaneity, honesty, innocence, simplicity, is held in high esteem. In folk art there are spontaneous values and freshness and authenticity that are highly valued by the elite as well.

Aside from being a cultural expression of society, in Tayub there is a human self orientation which is a spiritual means of society to God Almighty. The function of Tayub itself in general namely, as a form of gratitude with the spirit of spirituality [2].

In connection with Javanese philosophy, tayub art is a fertility rite, a meeting between the Father of Space and Motherland. This is symbolized by dancing in pairs between the pengibing and waranggana. This is similar to the Javanese people's view of the phallus yoni philosophy of fertility and balance in the cosmos cosmos of the Javanese people [3].

At the earth surgery ceremony, the pengibing or the dancer who performed first with the taek taek was the village elder. The pair of village elders and teasing in the dance is called earth surgery or dissecting the earth. The paired dance also symbolizes the relationship between men and women with land that is cut open or split to grow rice. In other words splitting the womb of a woman intended as splitting the earth earlier. Until now it turns out that Tayub is still often used for ceremonial ceremonies. However, it must be admitted that in the subsequent development of the erotic tayub dance movement then turned into entertainment or an exciting spectacle. When the tayub dance moves change only to a spectacle, it is not excessive if tayub is then used as a tourist attraction.

The meaning of dance is the beauty of the motion of the members of the human body that is moving, rhythmic and souled or given the meaning that dance is the beauty of the forms of the human body moving, having faith and having a harmonious spirit [4]. The existence of tayub art in the life of the community or the beginning of its appearance in the life of the Palace has a value or meaning, because art which is the work of human works still contains certain values and meanings. The meaning of tayub art, which here takes the concept of Edy Sedyawati that tayub art is the Art of the Palace which experiences developments and changes in people's lives in general [5].

Tayub has a meaning or meaning that from several aspects always accompanies it. These aspects, will reveal the existence of human identity as seen in the humanist nature (the essence of humanity). These qualities are seen in the expression of the motion, soul and passion of the performer in tayub art. Sometimes those traits lead on "side act", so it shows the negative aspects of tayub dance. Such dance is actually not only developed on the island of Java alone, even in the European world it has developed quite rapidly. This type of dance that has developed in Europe is referred to as walts, which is entertainment or social dance in the real sense (social or couple dance).

In the context of Cultural Studies a problem is not universally seen and analyzed, but how to comprehend and see in detail section by section, intertwining parts by parts becomes more comprehensive, as well as the goals and ideologies behind the phenomenon.

\section{Research Method}

This research entitled Local Wisdom Discourse: Performing Arts in Tayub Dance in Gesi Sragen Village is using qualitative analysis. A qualitative approach is a type of research whose findings are not obtained through statistical procedures and other calculations, but with examples of research on the life, history, behavior of a person, as well as on the role of the organization, movement social, or reciprocal relationship [6]. 
In the paradigm of Cultural Studies which is in the postmodernism space, with critical thinking space. Thus, theories have a function, including (1) a tool to clarify a phenomenon that arises in the problem search stage, (2) as a means of summarizing or selecting data at the data collection stage, (3) as a tool to sharpen studies at the analytical stage, must selected from theories that develop in the ideas of critical theories and adapted to the problem being overcome [7].

In this study Faucault's discourse theory becomes the main theory to answer various problems that have been formulated from the ontological, epistemological, and axiological. For the problems faced in this study, assisted with the theory of hegemony to understand why the discourse in the research problem is built and negotiations that occur in relationships that occur in the circle of community problems in the village of Gesi Sragen, which ultimately has implications for the construction of social and cultural behavior of the surrounding community.

\section{Results And Discussion}

\subsection{Tayub}

The word Tayub is indeed familiar to Javanese people. An anthropologist has defined tayub in his book "Javanese Religion" explains that tayub is an art that is favored by the community, especially among abangan, in contrast to prijajis, from the prijaji group mostly dislike tayub [8]. When in fact tayub itself is palace art which penetrated the coastal community.

According to the narrative of R.T Kusumakesawa the meaning of the Tayub dance is very different from what is still known today [9]. According to him his explanation, tayub was only in the palace, which was a dance performed by the king when he was giving lessons about leadership (Astha Brata) to the crown prince. By dancing this lesson is conveyed to the future king. There was no one else who witnessed it except for those four eyes who were directly involved. From the explanation above, it was explained that tayuban itself grew in the palace and spread to the people and now it developed into a social dance, synonymous with paired dances between sons and daughters.

In line with Mangkunegaran's notes, there is information that nayub is derived from two mataya words meaning dance, and guyub which means getting along together. An interpretation arises that tayub of two words becomes one: ma-ta-ya and gu-yub becomes tayub. Also added to the Panembahan Senapati period, the first King of Mataram, during a visit to the western region of Pajang, he was treated to a dance with a female dancer called teledhek or dedungik, a dance known as Nayuban.

In the explanation of the fifth volume of Centhini Fiber in tayuban it is explained that female dancers are referred to as taledhek or ledhek [10]. The word is interpreted as Nggeledhek which more or less means captivating, which is intended so that all the audience and especially the expectedfor ngibing in order to become interested in him. Both interested in dance style and in her beauty, so as not to be reluctant to spend money as an invitation to dance with Taledhek.

Departing from court dance which penetrated into social dance and even stealing community days, tayub performances seemed to be very popular with the community, which was colored by dance scenes in pairs of sons and daughters, namely between waranggana and 
pengibing. Until the tayub journey during the colonial period was colored with alcoholic drinks.

In his explanation, Geertz swooped in giving the understanding that tayuban is a combination of drinking and dancing parties, usually held at transitional ceremonies and so on. Customary drinking habits originate from the west, westerners carry customs for drinking, because the weather in the west is very cold, for that very warm drinks are treated very important for health. Therefore, in its journey tayub was colored with binge drinking.

This opinion is not in line with Prof. Dr. Poerbotjaroko who gave an explanation that the meaning of the word from Tayub through an article titled Najub, Najuban; (Read; Nayub, Nayuban), Poerbotjaroko gives an explanation that Nayub is not derived from the word tayub, but it comes from the word Sayub which means liquor or also to refer to stale food; by discarding the final letter turns into glazed which in Javanese Krama becomes sajeng, which means liquor; because the exchange "s" becomes "w" turns into a skillet or liquor (Bharatayudha poem II verse 10). The form of ngoko from wajeng is wayu which is half stale or tape into tape [11]. In the Mangkunegaran notes there is also a statement that nayub is derived from the word tayub which consists of two words namely mataya which means dance, and guyub which means getting along together. So it is thought that there will be a change from two words to one: ma-taya and gu-yub become tayub. It is clear that Tayub is closely related to an event that uses liquor as an important part of a ceremony.

It can be concluded that the use of liquor is an important part of the performance of Tayub and it has been ingrained, since the appearance of Tayub itself, then in its journey added to the influence the colonizers were later adopted by the indigenous people to always add liquor in the Tayub performance.

\subsection{Discourse}

In Indonesian, discourse is equated with discourse. This term is considered appropriate because it matches the original language (Latin). The meaning of "discourse" was introduced by Foucault in his professor's inaugural speech and through his book La archeoloie da savoir which had been published two years before his inauguration, as well as through his writings on madness. The rules, systems, and procedures are called Foucault with the term "discourse order" that is the whole conceptual area in which knowledge is constructed (formed and produced). Discourse in this sense is the whole field (domain) where language is used in certain settings. The domain is rooted in various practices of life, in institutions, and in human actions in general.

The discourse of madness in modern society is rooted in hospitals, psychiatric practices. In the broadest sense, discourse means everything that is written or spoken or that is communicated using signs. Discourse is a collection of statements. Hayden White defines discourse as "the basis on which to decide what will be determined as a fact in the issues discussed, and to determine the most appropriate way to understand the facts which are then established". Therefore, the study of texts, studies of history, culture, and claims of objectivity and truth must be postponed, because they have been influenced by rules, differences in meaning, and strategies similar to other narratives. Now the boundary between 'fact' and 'fiction' is increasingly blurred, because it needs to be examined closely [12] [13].

Rationality is considered to produce knowledge and discourse of truth. But Foucault warned, that when a discourse is born, then the discourse is actually already controlled, selected, organized, and redistributed according to the wishes of the creator. The discourse is constructed based on certain rules (episteme). For this reason, Foucault states, "truth has links to power systems". 


\subsection{Local Wisdom Discourse Performing Arts in Tayub Dance}

The concept unit of the local wisdom discourse sentence of an art performance consists of several elements, namely: (1). Discourse, (2). Local Wisdom, (3). Performing Arts in Tayub Dance.

Discourse in the meaning of Indonesian is discourse, according to Hayong (in Foucault, 2013: 2-3) as an explanation, definition, classification, and thinking about knowledge and abstract systems of human thought, which cannot be separated from power relations.

In the concept of Foucault, discourse as an activity of formation of meaning, is the essence of human relations, obtaining two major concepts namely knowledge (knowledge) and power (power). "Power is everywhere, it cannot be destroyed, it can only be controlled." Power produces knowledge (knowledge), and there is no relationship of power with the correlative constitution of that field of knowledge, and likewise, there is no knowledge that requires something, and at the same time is a relationship of power.

Local wisdom is commonly interpreted as the building of knowledge that originates from local values and potentials which are orally discouraged from generation to generation which are finally called traditional culture. However, it must be recognized that truth is not always present in the new (modern), but also in the traditional, even truth is spread throughout human experience, fragmented according to the space and time reality is in, and not just determined based on reason and rational. Local wisdom in the performance of tayub art, tayub art as the art of humanity is part of the results of the art culture of society / humans that grow and develop as a result of its existence. Dance still has meaning and function in the process of socialization. This process has three dimensions, namely between humans and humans, human beings with ultimate power, and humans with the natural existence of their environment.

According to M. Karno Kd, tayub art has a high philosophical meaning, namely tayub art is like a life that exists in humans various kinds of trials. Tayub art there are several terms in charge of duty, namely tledek, pengarih, and penglarih. Tledek is a dancer which means that tledek is tasked with tempting humans to do bad things, to persuade and to be likened to demons. The pengarih is to act as the adviser so as not to be tempted by the technology. While the penglarih acts as a persuader who persuades tledek to tease.

Local wisdom in the art performances of tayub sragen, tayub dance are performed as religious ceremonies, and traditional ceremonies, as a means of marriage, circumcision ceremonies, village cleansing ceremonies, ceremonial release ceremonies, spectacles or entertainment, and as a means of association. In the current development tayub dance as an asset of the Sragen Regency Government as a means of regional tourism assets. Based on the analysis of the discussion above, the local wisdom discourse forms a knowledge, where the knowledge is contained in a high philosophy which is where the art of Tayub is like a life that exists in humans. While the power lies in the tledek, pengarih and pengariari. These names have their respective ways. Tledek as tayub dancer, pengarih as adviser or community leader, and pengariari who persuades or regulates the course of tayub dance performance.

\section{Conclusion}

Discourse is a power that is everywhere, even the smallest individual can create discourse. In the discourse there is knowledge in which there is a relationship and form a power. In the phenomenon of tayub dance performance, tledek as a sindhen and dancer shows that there is a discursive formation that occurs in the Sragen gesi community. The occurrence of local 
wisdom discourse: art performance in tayub dance that is forming a knowledge, where the knowledge is contained in a high philosophy which is where tayub art is likened to a life that exists in humans, and power is in tledek, pengarih and pengariari. So the implications of the power possessed by Tledek, Pengarih, and Pengariarih through the discursive mechanism are not dull but productive.

\section{References}

[1] Nugroho Notosusanto. Masalah Penelitian Sejarah Suatu Pengenalan, (Jakarta: Yayasan Idayu, 1978.

[2] Setya Yuwono (ed), Tradisi dari Blora, Semarang: Citra Almamater, 1996.

[3] Sri Rochana Widyastutieningrum., TAYUB di Blora Jawa Tengah Pertunjukan Ritual Kerakyatan, (Surakarta : ISI Press Surakarta, 2007.

[4] Suara Merdeka, 27 Mei 1992, Koleksi Reksa Poestaka Mangkunegaran, No. G. 431, 1992.

[5] Majalah Nova, 22 Januari 1989, Koleksi Reksa Poestaka Mangkunegaran, No. G. 291, 1989.

[6] Hananta. "Usaha Pelestarian Seni Tari Tayub Wonogiri (Studi Kasus Tentang Perkembangan Kesenian Tari Tradisional di Kabupaten Wonogiri)”. Skripsi Fakultas Sastra dan Seni Rupa UNS, 1993.

[7] Wikan Awiroto. "Kesenian Tayub Dalam Upacara Bersih Desa Di Desa Karangsari Kecamatan Semin, Kabupaten Gunung Kidul”. Skripsi Fakultas Sastra dan Seni Rupa UNS, 1989.

[8] Danyang Subur. "Tari Tayub Garapan Baru Departemen Pendidikan Dan Kebudayaan Kabupaten Sragen (Sebuah Tinjauan Analisis Garap Gerak)”, Skripsi Fakultas Karawitan Institut Seni Indonesia Surakarta, 1996.

[9] Titis Pitana, Teori Sosial Kritis: Metode Dan Aplikasinya, (STAIN Press Purwokerto), 2014.

[10] Yasraf Amir Piliang, Semiotika Dan Hipersemiotika: kode, gaya, \& matinya makna, (Bandung: MATAHARI), 2010.

[11] Cris Barker, CULTURAL STUDIES Teori Dan Praktik, Yogyakarta: BENTANG PT. Bentang Pustaka, 2005.

[12] Jane C. Ollenburger dan Helen A. Moore. Sosiologi Wanita. Jakarta: PT. Rineka Cipta, 1996.

[13] K. Saddhono, "Integrating Culture in Indonesian Language Learning for Foreign Speakers at Indonesian Universities." J. of Lang. and Lit. vol. 6 no.2 pp. 349-353, 2015 